January 2021

\title{
The Problems with Patchwork: State Approaches to Regulating Insurer Use of Genetic Information
}

Jarrod O. Anderson

University of lowa

Anna C.F. Lewis

University of Oxford

Anya E.R. Prince

Georgetown University

Follow this and additional works at: https://via.library.depaul.edu/jhcl

Part of the Health Law and Policy Commons

\section{Recommended Citation}

Jarrod O. Anderson, Anna C. Lewis \& Anya E. Prince, The Problems with Patchwork: State Approaches to Regulating Insurer Use of Genetic Information, 22 DePaul J. Health Care L. (2021)

Available at: https://via.library.depaul.edu/jhcl/vol22/iss1/1

This Article is brought to you for free and open access by the College of Law at Digital Commons@DePaul. It has been accepted for inclusion in DePaul Journal of Health Care Law by an authorized editor of Digital Commons@DePaul. For more information, please contact digitalservices@depaul.edu. 


\title{
The Problems with Patchwork:
}

\section{State Approaches to Regulating Insurer Use of Genetic Information}

\author{
Jarrod O. Anderson ${ }^{1}$, Anna C.F. Lewis ${ }^{2}$, Anya E.R. Prince ${ }^{3}$
}

The growing availability of genetic testing in the clinical, research, and direct-to-consumer realms has caused people to fear that they will be discriminated against for their genes. In response, Congress passed the Genetic Information Nondiscrimination Act (GINA), which prohibits the use of genetic information in much of health insurance and employment. Importantly, this prohibition does not apply to life, long-term care, and disability insurance. While these lines of insurance are not federally prohibited from using an individual's genetic information, several states do regulate use of genetic information in these insurance lines. This paper presents a comprehensive 50 -state survey on regulation of how life, long-term care, and disability insurers can use genetic information. Overall, it shows that the use of genetic information in these lines of insurance is still relatively unregulated and that the divergent strategies adopted across states are both weak and problematic. Consistent and even regulation, whether from the federal government or through model legislation, is needed to adequately protect insurers and families alike.

\footnotetext{
${ }^{1}$ Juris Doctor, University of Iowa College of Law.

${ }^{2}$ Research Associate, E.J. Safra Center for Ethics, Harvard University.

${ }^{3}$ Associate Professor, University of Iowa College of Law. Research reported in this publication was supported by the National Human Genome Research Institute of the National Institutes of Health under Award Number R00HG008819. The content is solely the responsibility of the authors and does not necessarily represent the official views of the National Institutes of Health. The authors acknowledge the work of the students in Professor Prince's Fall 2018 Insurance Law course at the University of Iowa College of Law who contributed to the initial locating and comparing of state statutes and insurance regulations. The students in the insurance law class who contributed to underlying state data are Jarrod Anderson, Joao Castro, Chandler Elliott-Fehle, Nicci Coulter-Ledbetter, Elizabeth Davidson, Sarah Haack, Bryn Hedlund, Jung Min Kang, Benjamin Kramer, Libby Martzahn, Maxwell McDaniel, Bernadette Nelson, Will O'Brien, Olayinka Ope, Famatta Passawe, Matthew Roth, Elizabeth Vandenberg, and Mary Grace Warren. (Permission was received from all students to share their names in publication.)
} 


\section{Introduction}

"We now have discrimination down to a science..." -Gattaca, 1997

In March 2020, the Florida legislature quietly, but drastically, altered the legal landscape regarding the regulation of insurer use of genetic information. ${ }^{4}$ Until this point, no state barred life insurers from underwriting on the basis of genetic information and few prevented long-term care or disability insurers from doing the same. A bill passed by both chambers of the Florida legislature, with collectively 152 yeas and only 4 nays, prevents life, long-term care, and disability income insurers from considering genetic information when setting premiums and underwriting. ${ }^{5}$ This legislation protects individuals even if genetic information is linked to increased risk, something almost all other legislative actions across the U.S. fail to do. Florida's law thus represents protection against the sort of discrimination many feared would arise as genetic testing developed and flourished after the Human Genome Project: discrimination between individuals based on their genetic information. People began to worry that they could be prevented from getting health insurance or employment based on their genetic makeup. ${ }^{6}$ In response, Congress passed the Genetic Information Nondiscrimination Act (GINA), which prohibits the use of genetic information by covered health insurers and employers. ${ }^{7}$ Importantly, GINA's protections do not extend to other settings, and in particular it does not apply to other, non-health lines of insurance.

\footnotetext{
${ }^{4}$ H.R. 1189, 2020 Leg., Reg. Sess. (Fla. 2020).

${ }^{5}$ Fla. Senate, House of RePresentatives Staff Final Bill Analysis 1 (Jan. 29, 2020), https://www.flsenate.gov/Session/Bill/2020/1564/Analyses/2020s01564.bi.PDF (The law allows for an exception if the information formed part of a diagnosis. While disability insurance is no longer included in the text of the statute, the bill removed an exception so now disability income insurance falls under existing health insurer protections.). ${ }^{6}$ Mary R. Anderlik \& Mark A. Rothstein, Privacy and Confidentiality of Genetic Information: What Rules for the New Science?, 2 AnN. Rev. GenOMICS \& HuM. Genetics 401, 405 (2001).

${ }^{7}$ Genetic Information Nondiscrimination Act of 2008, 29 C.F.R. § 1635.1 (2020); see also Louise M. Slaughter, The Genetic Information Nondiscrimination Act: Why your Personal Genetics are Still Vulnerable to Discrimination, 88 SurgicAl Clinics 723, 724 (2008); see also Jessica L. Roberts, The Genetic Information Nondiscrimination Act as an Antidiscrimination Law, 86 Notre DAME L. ReV. 597, 597 (2011).
} 
Yet, underwriters for many different lines of insurance could be interested in incorporating genetic risk information into their process. After all, insurance is the business of risk allocation; one party, the policyholder, pays another, the insurer, to assume the risk that an event, such as an illness, loss of job, or death, will occur. ${ }^{8}$ Insurers have continuously sought methods to more accurately and reliably determine the risks they assume. ${ }^{9}$ When genetic testing reveals a policyholder's predisposition to certain disorders, an insurer may want to use that information to better determine how much coverage is likely to cost. Just as this is true in health insurance, it is also true in other medically underwritten insurance policies, like life, long-term care, and disability income insurance. While these lines of insurance are not federally prohibited from using a person's genetic information, several states have stepped in to address concerns of genetic discrimination and fill that gap.

Potential genetic discrimination in insurance stems from differences in treatment that could arise from accurate understandings of genetic risk information or from inaccurate understandings of such information. Both are problematic. In the former, individuals may become part of a 'genetic underclass' based on an inherited risk. In the latter, individuals could be harmed due to misinterpretations of a changing science. As we will show below, the legislation recently passed in Florida is almost unique in targeting discrimination even if based on accurate understanding of risk. Protections offered by other states are much weaker. Moreover, the lack of uniformity in protections, both in form and substance, dilutes their effectiveness.

\footnotetext{
${ }^{8}$ Ronen Avraham, The Economics of Insurance Law-A Primer, 19 ConN. INS. L.J. 29, 32 (2012).

${ }^{9}$ Tom Baker, Containing the Promise of Insurance: Adverse Selection and Risk Classification, 9 CONN. INS. L.J. 371, 377 (2002); Anya E.R. Prince, Insurance Risk Classification in an Era of Genomics: Is a 'Rational Discrimination' Policy Rational?, 96 NEB. L. REV. 624, 666 (2017) (discussing the arms race phenomenon of insurers finding new ways to parse risk).
} 
This article examines the state laws that regulate life, long-term care, and disability insurers' use of genetic information and calls for greater uniformity across states to address insurer use of genetic information. Several scholars have completed surveys of state laws that address genetic information and its implications outside the medical realm. Some, for example, were completed in the years leading up to GINA's passage. ${ }^{10}$ One such study found that forty-four states had enacted legislation addressing genetic privacy or genetic discrimination, and that these laws tended to deal with how insurers, including health, life, and disability insurers, and employers may obtain, use, and disclose genetic information. ${ }^{11}$ Other, more recent state surveys have taken a broad examination of laws covering genetic information-including, but not limited to genetic antidiscrimination laws. For example, Leslie Wolf and her team undertook a mammoth review of both federal and state laws related to human subjects research, access, use, and disclosure of genetic information, medical privacy laws, and disability discrimination laws. ${ }^{12}$ The National Human Genome Research Institute (NHGRI) at the National Institutes for Health (NIH) has maintained a compilation of statutes related to genomic privacy, research, newborn screening, and discrimination. ${ }^{13}$ According to the database, fifteen states have made legislative attempts in nonhealth lines of insurance since the passage of GINA, only four successfully. ${ }^{14}$ Acknowledging that

\footnotetext{
${ }^{10}$ See generally William F. Mulholland \& Ami S. Jaeger, Genetic Privacy and Discrimination: A Survey of State Legislation, 39 JURIMETRICS 317 (1999) (compiling over forty state statutes governing the disclosure of genetic information in employment and insurance).

${ }^{11} I d$. at 318 (discussing pre-GINA state laws that restricted the use of genetic information in employment and insurance contexts. Other pre-GINA examinations of state law focused on health insurance protections or employment.); see also Karen H. Rothenberg, Genetic Information and Health Insurance: State Legislative Approaches, 23 J.L. MED. \& ETHICs 312, 313 (1995); Karen Rothenberg et al., Genetic Information and the Workplace: Legislative Approaches and Policy Challenges, 275 SCIENCE 1755, 1755-56 (1997).

${ }^{12}$ Leslie E. Wolf et al., The Web of Legal Protections for Participants in Genomic Research, 29 Health Matrix: J.L. MED. 1, 6 (2019).

${ }^{13}$ Genome Statute and Legislation Database, NAT'L Hum. GenOme Res. Inst. (Aug. 3, 2020), https://www.genome.gov/about-genomics/policy-issues/Genome-Statute-Legislation-Database; see also Patricia Born, Genetic Testing in Underwriting: Implications for Life Insurance Markets, 38 J. INS. REG. 1, 13 (2019) (utilizing the NHGRI database to explore the variety of state laws in this area).

${ }^{14}$ NAT'L Hum. GENOME RES. INST., supra note 13 (outlining similar bills that were deemed duplicates and were not counted by the same legislature during the same session).
} 
much has changed within the genetic testing landscape since GINA, we have determined that a reexamination of the legal terrain is due-especially one narrowly focused on laws regulating insurer use of genetic information, since no survey has looked narrowly at this particular question since the passage of GINA.

Despite consistent dialogue and suggestions for regulation, use of genetic information in life, long-term care, and disability insurance remains comparatively unregulated. ${ }^{15}$ Furthermore, the regulations on the books vary in approach, scope, and definitional language. The resultant patchwork of protections leaves much to be desired. Family members who share the same genetic variants, but who do not live in the same state, may have variable legal protection. Healthcare providers and patients, too, lack clarity as to the scope of protections available to them. Informed consent documents for clinical genetic testing or genetic research, therefore often explain the provisions of GINA and note the gap in coverage for life, long-term care, and disability insurance, but generally do not provide any detail about what state level provisions would be relevant. This confusion and fear surrounding how insurers may use genetic information leads some to forego genetic testing altogether-a decision that could have dire consequences for personal and public health. ${ }^{16}$

\footnotetext{
${ }^{15}$ Dexter R. Golinghorst \& Anya E.R. Prince, A Survey of US State Insurance Commissioners Concerning Genetic Testing and Life Insurance: Redux at 27, 29 J. GenETIC COUNSELING 928, 932 (2020); see also Robert Klitzman et al., Should Life Insurers Have Access to Genetic Test Results?, 312 JAMA 1855, 1855 (2014); see also Amy L. McGuire \& Mary Anderlik Majumder, Two Cheers for GINA, 1 GenOME MED. 6, 7 (2009); see also Mark A. Rothstein, Time to End the Use of Genetic Test Results in Life Insurance Underwriting, 46 J.L. MED. \& ETHICs 794, 794 (2018); see also David Schultz, It's Legal for Some Insurers to Discriminate Based on Genes, NPR (Jan. 17, 2013), http://www.npr.org/blogs/health/2013/01/17/169634045/some-types-of-insurance-can-discriminate-based-ongenes; see also Sarah Zhang, The Loopholes in the Law Prohibiting Genetic Discrimination, ATLANTIC (Mar. 13, 2017), https://www.theatlantic.com/health/archive/2017/03/genetic-discrimination-law-gina/519216/.

${ }^{16}$ Mark A. Rothstein, supra note 15.
} 
Section II presents findings of an in-depth 50-state survey of state regulation in this area. ${ }^{17}$

Only 21 states explicitly restrict in some way the use of genetic information in life insurance, 18 in disability insurance ${ }^{18}$, and 14 in long-term care insurance (See Table 1 for a breakdown of these numbers across types of regulation). Across all categories, 25 states are represented, which means that half of U.S. states have no regulation specific to these lines of insurance and genetic information. Only 14 have some sort of regulation across all three lines, but as will be discussed, in some cases these protections can be quite minimal.

Section III argues for why this lack of consistency is a problem. First, it is very hard for individuals to understand what protections existing laws provide because of complex and nuanced regulation and differing definitions of terms across jurisdictions. Second, the variability poses several practical problems when implementing protections: 1) for those who move across state boundaries, it may be difficult to determine which law applies; 2) for those with family members

\footnotetext{
${ }^{17}$ Wolf et al., supra note 12; see also Genome Statute and Legislation Database, NAT'L HuM. GENOME RES. InST., https://www.genome.gov/about-genomics/policy-issues/Genome-Statute-LegislationDatabase? field content type value $=$ State $\% 20$ Statute \& field topic value=Privacy (last visited June 4, 2020); Learning Library, POL'Y SURVEILLANCE SYS., http://lawatlas.org/page/lawatlas-learning-library (last visited June 3, 2020) (The purpose of the 50-state survey was to determine national trends in state legislation regarding the use of genetic information in life, long-term care, and disability income insurance. It was sponsored by a grant from the NHGRI through the Ethical, Legal, and Social Implications ("ELSI") research program. The PI, Anya Prince, undertook the survey in Fall 2018 assisted by 20 law students at the University of Iowa College of Law. The methodology was modeled after the process developed by LawAtlas's Policy Surveillance program. This included: defining the scope of the project, developing a questionnaire, coding the law across all jurisdictions, and doubling checking the coding. Each student was assigned two or three states for which to complete a questionnaire that had been developed by the class. The results were double-checked in three main ways. First, each student's work was reviewed by other students as part of a quality control. Second, two authors of this paper (JA, AP) pulled the text of each statute cited in the codebook and reviewed - recoding as necessary. Finally, all results were checked against previous state surveys completed to identify differences in interpretation and determine potential gaps in coding.); see also NAT'L CONFERENCE COMM'Rs UNIF. LAWS, UNIFORM PROTECTION OF GENETIC INFORMATION IN EMPLOYMENT AND INSURANCE ACT 69 (2010) (hereinafter DRAFT UNIFORM LAW), https://www.uniformlaws.org/HigherLogic/System/DownloadDocumentFile.ashx?DocumentFileKey=492b47184206-353d-4d1d-e690089e20b7\&forceDialog $=0$.

${ }^{18}$ See, e.g., DRAFt UNIFORM LAW, supra note 17, at 14 (noting that "in many states, disability-income and longterm-care insurance are regulated as health insurance.") (States differ in how they define disability insurance. Some states specifically regulate disability income insurance - which is income replacement when someone is unable to work due to a disability. We note throughout the paper where state law is specific to this area. Other state definitions of disability insurance are broader and describe types of insurance more akin to health insurance, but that may also include disability income insurance. The state survey includes any laws that specifically mention disability or disability income insurance without parsing further applicability.).
} 
living in different states, there may be different legal protections for the same genetic information; and 3) for insurers, there may be difficulty in estimating the true impact of regulation. We discuss approaches to provide greater uniformity of protection. Section IV concludes.

\section{State Approaches}

There are two broad lenses through which to think about protection of genetic information: privacy and anti-discrimination. Under a privacy framework, genetic information is considered private information and the individuals to whom it belongs retain some control over when and how it is shared. Through an anti-discrimination lens, law and policy defines the uses of genetic information and, importantly, prohibits discriminatory use. At the federal level, GINA utilizes elements of both these approaches. ${ }^{19}$ Traditionally, GINA is considered an anti-discrimination bill that prohibits use of genetic information in decision-making in two specific sectors-health insurance and employment. ${ }^{20}$ However, GINA is actually much broader than this as it prohibits covered health insurers and employers from collecting (not just using) genetic information except in limited circumstances. ${ }^{21}$ This gives individuals more control over whether and how their genetic information makes its way into the hands of employers and health insurers.

Broadly, the privacy approach for genomic legislation begins with the premise that genetic information is particularly personal, or private, information. ${ }^{22}$ Therefore, "no collection or analysis of an individual's DNA should be permitted without an informed and voluntary authorization by

\footnotetext{
${ }^{19}$ See, e.g., Jessica L. Roberts, The Genetic Information Nondiscrimination Act as an Antidiscrimination Law, 86 Notre DAME L. REV. 597, 617-19 (2011) (arguing that Congress failed to approach this as a privacy bill, but rather chose to adopt it as an antidiscrimination law).

${ }^{20}$ Genetic Information Nondiscrimination Act of 2008, 29 C.F.R. $§ 1635.1$ (2010) (Title I applies to health insurance and Title II applies to employment decisions.).

${ }^{21} 42$ U.S.C. § 2000ff-1(b) (2008) (barring employer acquisition of genetic information with delineated exceptions); see, e.g., 29 U.S.C. § 1182(c)(1) (2018) (limiting the acquisition of genetic information by health insurers).

${ }^{22}$ George J. Annas et al., Drafting the Genetic Privacy Act: Science, Policy, and Practical Considerations, 23 J.L. MED. \& ETHICs 360, 360 (1995) (noting that genetic information is uniquely private because it can predict propensity for disease, it provides information about the individual and family members, and it could be stigmatizing).
} 
the individual or the individual's legal representative." 23 Requirements put in place designed to protect privacy are thus framed in terms of informed consent.

The anti-discrimination approach instead places restrictions on the information insurers may use, regardless of their level of access. There are three main methods: (1) general restrictions on use of genetic information, (2) prohibitions for use of a particular type of test, and (3) actuarial justification for use requirements.

On the state level, privacy and anti-discrimination approaches are rarely combined. Instead the restrictions generally fall into one of three categories: (A) informed consent for use requirements, (B) anti-discrimination approaches, and (C) other approaches. Some states have varying statutes that cover multiple approaches, but none are integrated into a unified legislative strategy as in GINA.

\begin{tabular}{|c|c|c|c|c|c|c|}
\hline \multirow{2}{*}{$\begin{array}{c}\text { Insurance } \\
\text { Lines }\end{array}$} & \multirow{2}{*}{$\begin{array}{l}\text { Informed } \\
\text { consent } \\
\text { requirements }\end{array}$} & \multicolumn{3}{|c|}{ Anti-discrimination } & \multirow[t]{2}{*}{ Other } & \multirow{2}{*}{$\begin{array}{l}\text { Explicit } \\
\text { regulation } \\
\text { in this line } \\
\text { of } \\
\text { insurance }^{\wedge}\end{array}$} \\
\hline & & $\begin{array}{c}\text { Ban on } \\
\text { use }\end{array}$ & $\begin{array}{c}\text { Bar use of } \\
\text { a particular } \\
\text { test }\end{array}$ & $\begin{array}{l}\text { Use with } \\
\text { actuarial } \\
\text { justification }\end{array}$ & & \\
\hline Life & 11 & 1 & 4 & 7 & 12 & 21 \\
\hline Disability & 10 & $3 *$ & 1 & 8 & 12 & 18 \\
\hline $\begin{array}{l}\text { Long-term } \\
\text { Care }\end{array}$ & 7 & 2 & 0 & 6 & 9 & 14 \\
\hline
\end{tabular}

*In one state $(\mathrm{CO})$, only applicable to group disability insurance. ${ }^{\wedge}$ Because some states regulate use of genetic information in multiple ways, this number is not additive across categories of regulation.

${ }^{23}$ Id. at 361 . 
Table 1: Number of states regulating life, disability, and long-term care insurance broken down by legislative approach. List of states for each category are given in the main text.

\section{A. Informed Consent Requirements Approach}

Informed consent provisions arise in many types of genomic-related legislation, including those relating to research, clinical care, and public health. ${ }^{24}$ State statutes vary in their proscription of which entities must obtain informed consent, and for which tasks. There are four primary categories of activities surrounding genetic information necessary for complete informed consent: collection, analysis, retention, and disclosure. The strongest statute would need to require authorization for all four categories. Even if one authorizes someone to analyze their genetic test results, if that entity can then disclose the information to third parties without authorization, the individual's privacy is still threatened. It also matters whether a law regulates genetic material or the genetic information that arises from it. For example, a law could provide for informed consent related to the retention of one's DNA, but leave vulnerable the information derived from the analysis of that material, which can then be retained for use without authorization or consent.

Requiring informed consent or authorization is a common approach used by states to regulate genetic information in the context of insurance. These laws, however, rarely address informed consent across all four categories of collection, analysis, retention, and disclosure. In several states, broad genetic privacy legislation requires informed consent related to genetic testing without specifically mentioning insurance. ${ }^{25}$ These statutes are likely broad enough to include

\footnotetext{
${ }^{24}$ NAt'L Hum. GenOme Res. Inst., supra note 17; see also Kayte Spector-Bagdady et al., Analysis of State Laws on Informed Consent for Clinical Genetic Testing in the Era of Genomic Sequencing, 178 AM. J. Med. Genetics 81, 84-85 (2018).

${ }^{25}$ AlASKa Stat. ANN. $§ 18.13 .010$ (West 2020) (“[A] person may not collect a DNA sample from a person, perform a DNA analysis on a sample, retain a DNA sample or the results of a DNA analysis, or disclose the results of a DNA analysis unless the person has first obtained the informed and written consent of the person."); OR. REV. STAT. ANN. § 192.535 (West 2020) (“A person may not obtain genetic information from an individual, or from an individual's DNA sample, without first obtaining informed consent of the individual"); S.D. CoDIFIED LAWs § 3414-22 (2020) ("No person may order or perform a predictive genetic test without first obtaining the written, informed consent of the person to be tested.") (Other states have statutes that on their face appear to provide broad
} 
insurers and they often address several or all of the categories of consent. Other states have explicit informed consent or authorization requirements, but they are specific to tests ordered by physicians. ${ }^{26}$ This survey focuses on statutes with informed consent or authorization provisions that specifically target insurance, whether by including insurance in the language of the statute or by housing the informed consent provision within the insurance code. This method of regulation is relatively pervasive compared to the categories of anti-discrimination legislation discussed below.

The state laws relating to informed consent, genetics, and insurance are varied and therefore difficult to consolidate into categorizations. Broadly, eleven states-Arizona, California, Colorado, Delaware, Florida, Maine, Minnesota, Nevada, New Jersey, New York, and Oregonrequire some level of informed consent or authorization related collection or analysis of genetic information and life insurance. ${ }^{27}$ Ten states-Arizona, California, Colorado, Delaware, Florida,

requirements, but statutorily may not). See, e.g., S.C. CODE ANN. § 38-93-50 (2020) (stating it is "unlawful to perform a genetic test on an individual without first obtaining specific informed consent.") (The statute has exceptions, such as for law enforcement or paternity testing. However, the section is housed in a chapter that "applies to health insurance coverage." Making it unclear whether the informed consent provisions only are meant to apply to health insurers, as the applicability provision indicates, or to a broader group performing genetic testing, as the exceptions would indicate.) Id. § 38-93-20. But see N.M. STAT ANN. § 24-21-3(D) (2020) (The law exempts life, disability income, and long-term care insurers from the general informed consent requirements and only requires them to give written notification that genetic information "may be used, transmitted or retained solely for the purpose of conducting and administering the business of life, disability income or long-term care insurance."). ${ }^{26}$ Mich. COMP. LAWS ANN. § 333.17020(1) (West 2020) (“"A] physician . . . shall not order a ... genetic test without first obtaining the written, informed consent of the test subject."); NEB. REV. STAT. ANN. § 71-551(1) (West 2020) ("[A] physician ... shall not order a predictive genetic test without first obtaining the written informed consent of the patient to be tested ... that confirms that the physician ... has explained, and the patient ... understands ... [t] he nature and purpose of the ... test."').

${ }^{27}$ ARIZ. REV. STAT. ANN. § 20-448.02 (2020) ("[A] person shall not order or require the performance of a genetic test without first receiving the specific written informed consent of the subject."); CAL. INS. CODE § 10148(a) (West 2020) ("An insurer that requests an applicant to take a genetic characteristic test shall obtain the applicant's written informed consent for the test."); ColO. REV. STAT. ANN. § 10-3-1104.7(10)(a) (West 2020) (“[A]n insurer shall not require the performance of or perform a genetic test without first receiving the specific, written, informed consent of the subject."); DEL. CODE ANN. tit. 16, § 1202 (West 2020) (formerly designated as Section 1221) (Delaware's law is an informed consent statute of broad applicability; however, it does have a requirement specific to insurance: DEL. CoDE ANN. tit. 16, § 1201(4)(d) (West 2020)) ("For the purpose of obtaining insurance, there may be a single signing [of a consent form] which shall allow the obtaining, retaining and disclosure of genetic information."); FLA. STAT. ANN. § 760.40(2) (West 2020) ("DNA analysis may be performed only with the informed consent of the person of the person to be tested."); ME. STAT. tit. 24-A, § 2159-C(3)(B) (2020) ("If . . an insurer uses the results of a genetic test ... the insurer shall ... obtain the individual's authorization.); MinN. STAT. ANN. § 72A.139(5) (West 
Indiana, Maine, New Jersey, New York, and Oregon—require the same for disability insurance. ${ }^{28}$ Seven states — Arizona, Delaware, Florida, Indiana, Maine, New York, and Oregon — require it for collection and analysis in long-term care insurance. ${ }^{29}$

Several state rules regarding insurance and informed consent require the state insurance regulator to develop a standard informed consent document ${ }^{30}$ or to approve the consent form used by insurers. ${ }^{31}$ The requirements for informed consent language are varied, but often include elements disclosing the nature of the test and how the information obtained may be used. Some states also require information about what data will be retained and what will be disclosed to which entities, so the documents may encompass consent for retention and disclosure as well. ${ }^{32}$ This,

2020) ("If an individual agrees to take a genetic test, the life insurance company ... shall obtain the individual's written informed consent for the test."); NEV. ReV. StAT. ANN. § 629.151 (West 2020) ("It is unlawful to obtain any genetic information of a person without first obtaining the informed consent of the person ....") (Note, however, that Section 629.131 states that several provisions, including the consent provision, "do not apply to any action taken by an insurer ... relating to a policy that provides coverage for long-term care or disability income."); N.J. STAT. ANN. § 17B:30-12(f) (West 2020) ("If . . . [a life, annuity, or disability income] insurer will use the results of a genetic test ... this insurer ... shall obtain the individual's written informed consent"); N.Y. INS. LAW § 2615(a) (McKinney 2020) ("No authorized insurer ... shall request or require an individual proposed for insurance coverage to be the subject of a genetic test without receiving the written informed consent of such individual prior to such testing.”); OR. REV. STAT. ANN. § 746.135(1) (West 2020) (“If a person asks an applicant for insurance to take a genetic test ... the use of the test shall be revealed ... and the person shall obtain the specific authorization of the applicant.").

28 ARIz. Rev. Stat. Ann. § 20-448.02 (2020); Cal. Ins. Code § 10148 (West 2020); Colo. Rev. Stat. AnN. § 103-1104.7(10)(a) (West 2020) (only for non-group plans); DEL. CODE ANN. tit. 16, § 1202 (West 2020); N.Y. INS. LAW § 2615(a) (McKinney 2005); FlA. STAT. § 760.40 (2009); IND. CodE ANN. § 16-39-5-2(d) (West 2020) (“[A]n insurance company other than a life insurance company may not obtain the results of any genetic screening or testing without a separate written consent.”); ME. REV. STAT. ANN. tit. 24-A, § 2159-C(3)(B) (2020); N.J. REV. StAT. ANN. § 17B:30-12 (West 2020); Or. REV. STAT. § 746.135 (2020).

${ }^{29}$ Ariz. Rev. Stat. AnN. § 20-448.02 (2020); Del. Code ANN. tit. 16, § 1202 (West 2020); N.Y. Ins. LAW § 2615(a) (McKinney 2005); Fla. Stat. § 760.40 (2009); Ind. Code ANN. § 16-39-5-2(d) (West 2020); Me. ReV. STAT. ANN. tit. 24-A, § 2159-C(3)(B) (2020); OR. REV. STAT. § 746.135 (2020). (Note, Colorado's informed consent provision is broadly written, so it would apply to long-term care insurers, however other provisions, discussed below, prevent long-term care insurers from using genetic information, so they should not be in the position to require or perform test results).

${ }^{30}$ See, e.g., COLO. ReV. StAT. ANN. § 10-3-1104.7(10)(a) (West 2020) (mirroring language from Arizona); OR. REV. STAT. § 746.135(1) (2020); CAL. CODE REGS. tit. 10, §§ 2218.20, 20-448.02(A) ("Written consent shall be in a form prescribed by the director."); OR. ADMIN. R. 333-025-0140(1)(c) (2020).

${ }_{31}$ See, e.g., Ind. CodE ANn. § 16-39-5-2(d) (West 2020); MinN. StAT. AnN. § 72A.139(5) (West 2020).

32 See, e.g., Del. Code AnN. tit. 16, § 1201(4)(d) (West 2020); FlA. STAT. § 760.40 (2009). 
however, is not true across the board. Here we highlight a few aspects of these informed consent laws.

New York's law exemplifies a broad statute that applies to all lines of insurance. ${ }^{33} \mathrm{New}$ York Consolidated Law Section 2615 prohibits all insurers from requesting or requiring "an individual proposed for insurance coverage to be the subject of a genetic test without receiving the written informed consent of such individual prior to such testing, in advance of the test." The law goes on to define what is required to satisfy written informed consent, including seven different disclosures about the test and the signature of the person being tested. One disclosure must state that the sample will be destroyed after testing, although it does not speak to the results of the test. ${ }^{34}$ Finally, the law protects the information once it is collected by deeming it confidential and requiring additional informed consent for further disclosure.

In contrast, Minnesota has a comparatively narrow informed consent law, authorizing life insurers to use genetic information, but requiring them to obtain written informed consent. "Written informed consent must include, at a minimum, a description of the specific test to be performed; its purpose, potential uses, and limitations; the meaning of its results; and the right to confidential treatment of the results. The written informed consent must inform the individual that the individual should consider consulting with a genetic counselor prior to taking the test and must state whether the insurer will pay for any such consultation." 35

Indiana provides an example where authorization is required for collection of results rather than simply consent for undergoing genetic testing. Although the provision does not apply to life insurers, it states that an insurer "may not obtain the results of any genetic screening or testing...

\footnotetext{
${ }^{33}$ N.Y. INS. LAW § 2615(a) (McKinney 2020).

${ }^{34} I d . \S 2615(\mathrm{~b})(7)$.

${ }^{35}$ MinN. STAT. § 72A.139(5) (2019).
} 
without a separate written consent by an individual..."36 This broader approach addresses both analysis of an individual's material and gives some control over the data resulting from a test as well.

No matter the scope and breadth of the informed consent provisions across state lines, these laws all have a fatal flaw - the power differential between the insurance company and the individual applicant or policyholder. While it is beneficial for consumers to be informed of aspects of genetic testing and the potential ways that insurers may use their information, there is little true choice for consumers to decline consent to these uses. Failure to consent to testing could lead to the inability to obtain insurance from the company. For example, if an insurer were to request that an individual undergo testing as part of a life insurance application and that individual declined consent, the insurer refuse to consider the insurance application or charge higher rates. ${ }^{37}$ Thus, requirements for authorization and consent to testing and use of genetic information provide some privacy protections and inform individuals of important features of testing and use, but are inadequate to completely protect individuals who simultaneously wish to access insurance and are not comfortable with what they are consenting to.

B. Anti-discrimination Approach

Under the anti-discrimination framework, regulations are designed to prevent certain entities from using genetic information in certain ways, although there are a myriad of different

\footnotetext{
${ }^{36}$ IND. CODE ANN. § 16-39-5-2 (West 2020).

${ }^{37}$ See also MASS. GEN. LAWS ch. 175, § 108I (2020) ("In the provision of insurance against disability from injury or disease or policies providing for long term care in the commonwealth, a company ... may ask on an application ... whether or not the applicant has taken a genetic [test] .... The applicant is not required to answer any questions concerning genetic testing. Any application requesting this information must contain or be accompanied by language informing the applicant that the applicant is not required to answer any questions in connection with genetic testing as defined in this section and language informing the applicant that the failure to do so may result in an increased rate or denial of coverage.")
} 
approaches that restrict use of genetic information. ${ }^{38}$ In the US, the majority of states default to a status quo, where insurers are left to "develop their own rules pertaining to the use of genetic information in connection with insurance contracts without intervention from the government." ${ }^{\prime 39}$ In general, this means that insurers may consider the results of a genetic test that is linked to increased risk in ratemaking or underwriting decisions. For example, positive tests for Lynch Syndrome, a genetic predisposition to colon and endometrial cancer, or Huntington's Disease, a genetic disease that causes nerve cells to progressively deteriorate, could play a role in whether a person gets insurance, and how much it costs. As noted above, in 2020, Florida became the first state to adopt a prohibitive approach in the context of life insurance. Most state restrictions, however, fall in the space between full prohibition and the status quo. Below, we highlight the range of approaches employed at the state level, beginning with the strictest bans to more limited legislation.

As a preliminary note, in all cases of genetic anti-discrimination regulation, it is important to consider the definition of genetic information - that is, to understand the scope of the information that is protected. GINA defines genetic information to include, not just the results of a genetic test, but also family medical history, participation in genetic research, and use of genetic

\footnotetext{
${ }^{38}$ Yann Joly et al., Comparative Approaches to Genetic Discrimination: Chasing Shadows?, 33 TrEnds GENETICS 299, 300 (2017). (The policies adopted in the US are really quite limited compared to the diverse set of strategies utilized elsewhere. Jurisdictions across the globe, for example, have policies that range from including genetic information in a human rights law, creating a moratorium agreement between the insurance industry and government, barring the use of genetic information in certain sectors, or maintaining the status quo. One survey of various global approaches to regulation in this area identified six main approaches: 1) fair limits approach (creating a monetary threshold over which insurers cannot use genetic information); 2) human rights approach; 3) prohibitive approach; 4) moratorium approach; 5) rational discrimination approach (allowing the use of only genetic information that has been found to meet scientific and actuarial standards); and 6) status quo.); see Yann Joly et al., Genetic Discrimination in Private Insurance: Global Perspectives, 29 NEW GeNETICS \& SOC'Y 351, 355-56 (2010); see also Anya E.R. Prince, Insurance Risk Classification in an Era of Genomics: Is a 'Rational Discrimination' Policy Rational?, 96 NEB. L. REV. 624, 666 (2017) (discussing the possibility of a rational discrimination policy approach in the US context).

${ }^{39}$ Yann Joly et al., supra note 38, at 356 (defining the status quo policy approach).
} 
services, such as going to see a genetic counselor. ${ }^{40}$ On the state level, this definition varies from state to state, but never is it equally broad. In most cases, the definition is limited to the results of genetic testing, although, in some cases discussed below, the law specifically mentions the genetic test results of family members. Although family medical history can provide some information about an individual's genetic risk, no state prevents life, long-term care, or disability insurers from using such history - the focus of current state efforts is on the results of an individual's genetic test.

\section{Full Prohibitions on Use of Genetic Information}

Very few states fully prohibit the use of genetic information in life, long-term care, and disability insurance. In fact, this method of regulation is the least common. Prior to 2020, no states prohibited the use of genetic information in life insurance. One state-Colorado-banned its use in long-term care and, in the group context, disability insurance. ${ }^{41}$ The law states that "[a]ny entity that receives information derived from genetic testing may not seek, use, or keep the information for any nontherapeutic purpose or for any underwriting purpose connected with the provision of group disability insurance or long-term care insurance coverage." ${ }^{\prime 2}$ This provision is exceedingly clear, directly placing the use of genetic information out of reach to long-term care and group disability insurers who would use it to make underwriting decisions. Further, the law clarifies that

\footnotetext{
${ }^{40} 29$ U.S.C.A. $\S 1191 \mathrm{~b}(6)(\mathrm{A})-(\mathrm{B})$ (West 2020).

${ }^{41}$ Colo. Rev. Stat. AnN. § 10-3-1104.7(3)(a)-(b) (West 2020) (barring use of information derived from genetic tests).

${ }^{42} I d$. $\S 10-3-1104.7(3)(b)$ (outlining the prohibition in Colorado's law explicitly forbids the use of genetic information for underwriting purposes within long-term care and group disability insurance, and "any nontherapeutic purpose" as well); Id. § 10-3-1104.7(3)(a)-(b) (introducing the slight ambiguity because a prohibition on the use of genetic information for any nontherapeutic purpose could be interpreted broadly, while a prohibition on its use in two specified lines of insurance is read narrowly. Given its stated intent, it could be that the law prohibits the use of genetic information broadly, and the specific mention of insurance is meant to be illustrative, not restrictive. However, it is more likely true that the use of genetic information is only prohibited within these lines of insurance, and that its use in other lines of insurance, such as life insurance, is still unregulated. A closer look at how these laws have been interpreted is necessary to know more).
} 
the "intent of this section is to prevent information derived from genetic testing from being used to deny access to group disability insurance or long-term care insurance coverage." It is interesting that the law narrows the prohibition of genetic information in disability insurance to the group context as these plans are generally not individually underwritten, so an individual's genetic test result would already be unlikely to be considered in the group context. Another state-Arizonabars disability insurers from rejecting an application or determining rates "in the absence of a diagnosis of the condition related to information obtained as a result of a genetic test." 43 Florida's recent legislation makes it the first state to bar the use of genetic information across all three insurances - life, long-term care, and disability insurance. ${ }^{44}$ The law carves out an exception for medical diagnoses made on the basis of genetic information, adding a distinction between predictive and diagnostic information that we will discuss further below.

Other sources have indicated additional states that have strong bans on the use of genetic information; however this analysis does not include them in this category for various reasons. ${ }^{45}$ For example, Vermont is sometimes included in media and other surveys as having a full ban on use; however the language of the bill states that "[n]o policy of insurance offered for delivery or

\footnotetext{
${ }^{43}$ ARIZ. REv. StAT. ANN. § 20-448(F) (2020) (defining disability insurance as "insurance against bodily injury, disablement or death by accident or accidental means, or the expense thereof, or against disablement or expense resulting from sickness, and every insurance appertaining thereto.”).

${ }^{44}$ FLA. SENATE, supra note 5, at 5-6.

${ }^{45}$ Three states are worth noting. First, Idaho's statute could be characterized as unclear, but we included under actuarial justification. IDAHO CODE ANN. § 41-1313 (West 2020) is titled "Unfair discrimination - Life insurance, annuities, and disability insurance." It includes two sections ( $1 \& 2)$, "unfair discrimination in life insurance" and "disability insurance." It then has a section (3) that states that "No person shall discriminate on the basis of a genetic test or private genetic information ... in . . . disability insurance or health benefit plan." Disability insurance is defined as "[i]nsurance of human beings against bodily injury, disablement, or death by accident or accidental means, or the expense thereof, or against disablement or expense resulting from sickness, and every insurance appertaining thereto." Id. $\S 41-503$. It is unclear whether "discrimination" in section 3 refers to unfair discrimination or to a broader conception of discrimination and whether disability income insurance is included in the state definition of disability insurance. Second, as will be discussed further below, although Maryland has been included by some surveys as having a ban (see, e.g., Wolf et al., supra note 12, at 58), it allows for use if there is actuarial justification. Finally, the Uniform Law Commission included Kansas as having a ban for disability and long-term care insurance. Kansas law on genetics and insurance is, quite frankly, one of the most confusing statutes drafted in this area. It is extremely difficult to understand the clear purpose of the statutory language, but we included it in our actuarial justification section to avoid the risk of overestimating protections. DRAFT UNIFORM LAW, supra note 17.
} 
issued in this State shall be underwritten or conditioned on the basis of: 1) any requirement or agreement of the individual to undergo genetic testing; or 2) the results of genetic testing of a member of the individual's family." ${ }^{" 46} \mathrm{We}$ do not categorize this as a full ban since the language of the statute appears to still allow for insurer consideration of an individual's existing test results. It is therefore included in the other category, described below. Incidentally, a bill currently pending in the 2020 legislative session would create a ban as it adds a provision that no insurance can be underwritten on the basis of "genetic information of the individual that may be associated with a potential genetic condition in that individual but that has not resulted in a diagnosed condition in the individual." ${ }^{47}$ The proposed Vermont bill would also expand the definition of genetic information to include family medical history. This bill passed the senate in May 2020 and was referred to the House Committee on Health Care. However, a new session of the state Congress began in 2021.

\section{Prohibitions on the Use of Particular Genetic Tests}

Some states have statutes which fully prohibit the use of a certain genetic test in life, longterm care, or disability insurance. This regulatory method, like the full prohibitions discussed above, is also relatively uncommon. Only four states-California ${ }^{48}$, Florida ${ }^{49}$, North Carolina ${ }^{50}$, and Tennessee ${ }^{51}$ —ban particular types of genetic conditions from use in life insurance, and only one state-California ${ }^{52}{ }^{53}$ - bars particular types of genetic conditions from use in disability

\footnotetext{
${ }^{46}$ Vt. StAT. AnN. tit 18, § 9334(a) (West 2020).

${ }^{47}$ S. 197, 30th Gen. Assemb., Reg. Sess. (Vt. 2020) (as passed by the Vermont Senate on May 21, 2020).

${ }^{48}$ CAL. INS. CODE $§ 10143$ (a) (West 2020) (protecting individuals with a carrier status).

${ }^{49}$ FLA. STAT. ANN. $\$ 626.9706$ (West 2020) (protecting individuals with a sickle cell trait).

${ }^{50}$ N.C. Gen. STAT. ANN. § 58-58-25 (West 2020) (protecting individuals with sickle cell or hemoglobin traits).

${ }^{51}$ TENN. CODE ANN. § 56-7-207 (West 2020) (protecting individuals with sickle cell or hemoglobin traits).

${ }^{52}$ INS. $§ 10143$ (protecting individuals with a carrier status).

${ }^{53} \S 626.9706$ (protecting individuals with a sickle cell trait).
} 
insurance. ${ }^{54}$ No states have enacted this type of prohibition in the realm of long-term care insurance. Maryland has a law that prohibits insurers from considering "sickle-cell trait, thalassemia-minor trait, hemoglobin C trait, Tay-Sachs trait, or a genetic trait that is harmless in itself". ${ }^{55}$ However, this law does allow the use of these traits if the insurer has actuarial justification. Therefore, this state law is a hybrid between the ban on specific traits and the actuarial justification policy strategy discussed in further detail below. ${ }^{56}$

What all of these laws have in common is that they focus on the results of carrier tests. There are some genetic conditions that are recessive, meaning that an individual must carry two copies of a genetic variant (one from the biological mother and one from the biological father) in order to be at risk for or develop the condition. Individuals who only carry one copy are called 'carriers'. In general, these carriers will not exhibit symptoms of the condition, but may risk having children with the condition. ${ }^{57}$

California's law prohibits life and disability insurers from refusing to issue or renew a policy "solely by reason of the fact that the person to be insured carries a gene which may, under some circumstances, be associated with disability in that person's offspring, but which causes no adverse effects on the carrier." ${ }^{n 8}$ The other laws in this area center around prohibition of the use of

\footnotetext{
${ }^{54} I d$. $\S 626.9707$ (prohibiting the use of sickle cell trait in disability insurance, although it is limited to policies providing "coverage for any medical treatment or service authorized and permitted to be furnished by a hospital, clinic, health clinic, neighborhood health clinic, health maintenance organization, physician, physician's assistant, nurse practitioner, or medical service facility or personnel.").

${ }_{55}^{55}$ M. Code ANN., INS. § 27-208(a)(3) (West 2020).

${ }^{56} I d . \S 27-208(\mathrm{~b})(3)(\mathrm{ii})$.

${ }^{57}$ Aaron C. Miller et al., Cystic Fibrosis Carriers Are at Increased Risk for Wide Range of Cystic Fibrosis-Related Conditions, 117 PROC. NAT'L ACAD. SCI. U.S. 1621, 1625 (2020) (discussing the growing understanding that being a carrier for certain genetic conditions can be associated with symptoms and complications); see also M. Mila et al., Fragile X Syndrome: An Overview and Update of the FMR1 Gene, 93 CLINICAL GENETICS 197, 199 (2018); Rahki P. Naik \& Carlton Haywood Jr., Sickle Cell Trait Diagnosis: Clinical and Social Implications, 1 AM. SoC’Y Hematology 160, 164-65 (2015); see also Anya E.R. Prince \& Myra I. Roche, Genetic Information, NonDiscrimination, and Privacy Protections in Genetic Counseling Practice, 23 J. Genetic Counseling 891, 896 (2014) (highlighting the interplay between GINA and symptoms associated with carrier status).

${ }^{58}$ CAL. INS. CODE $§ 10143$ (a) (West 2020) (protecting individuals with a carrier status).
} 
sickle-cell trait or hemoglobin $\mathrm{C}$ trait. This is referring to carrier status for the recessive diseases sickle cell anemia and hemoglobin C disease. In the 1970s, there were state and national public health measures that increased screening for sickle cell, however these efforts were critiqued, in part due to concerns about stigmatization and equitable access to life insurance and employment. ${ }^{59}$ Both diseases are more common in Black populations and therefore concerns of stigmatization overlap with concerns of racial discrimination and equity. ${ }^{60}$ Florida Statute Section 626.9706 specifically prohibits the use of sickle-cell trait status in life insurance. This provision, as a part of Florida's Unfair Insurance Trade Practices law, clearly prohibits an authorized insurer from refusing to provide life insurance to someone who "has the sickle-cell trait," or from using that trait as the sole basis for charging higher premiums.

North Carolina Statute Section 58-58-25 prohibits life insurers from refusing to insure a person or charge that person higher premiums, "solely by reason of the fact that the person to be insured possesses sickle cell trait or hemoglobin C trait." Tennessee's law utilizes the same language. ${ }^{61}$ All of these laws were originally passed in the 1970s and 1980s, before genetic testing was developed, so the definitions do not include specific mentions of a genetic marker or test. ${ }^{62}$

\footnotetext{
${ }^{59}$ Robert M. Schmidt \& William J. Curran, A National Genetic-Disease Program: Some Issues of Implementation, 295 New Eng. J. Med. 819, 819-20 (1976); see also Yann Joly et al., Looking Beyond GINA: Policy Approaches to Address Genetic Discrimination, 21 AnN. ReV. Genomics \& Hum. Genetics 2.1, 2.2 (2020) (noting that discussions surrounding sickle-cell anemia were one of the first instances of concern about life insurance discrimination and genetics).

${ }^{60}$ Regina H. Kenen \& Robert M. Schmidt, Stigmatization of Carrier Status: Social Implications of Heterozygote Genetic Screening Programs, 68 AM. J. Pub. HeAlth 1116, 1118 (1978).

${ }^{61}$ TENN. CODE ANN. § 56-7-207 (West 2020).

${ }^{62}$ Id. (outlining Tennessee's definition of sickle cell trait as "the major natural hemoglobin components present in the blood of the individual are hemoglobin A (normal) and hemoglobin S (sickle hemoglobin) as defined by standard chemical and physical analytic techniques, including electrophoresis; and the proportion of hemoglobin A is greater than the proportion of hemoglobin $\mathrm{S}$ or one (1) natural parent of the individual is shown to have only normal hemoglobin components (hemoglobin A, hemoglobin A2, hemoglobin F) in the normal proportions by standard chemical and physical analytic tests.”).
} 
Today, both traits - i.e. carrier status for both of these diseases - can be identified through genetic testing. ${ }^{63}$

In general, carrier status does not give information about the health of an individual. ${ }^{64}$ Carrier status information hence ought not to be relevant to medical underwriting. The existence of these laws illustrates ongoing issues with genetic information: genetic literacy is low, even among medical professionals and insurers. In the era when these laws were passed, there was critique about the lack of clarity in science, law, society, and policy between sickle-cell anemia versus sickle-cell trait. ${ }^{65}$ Adverse treatment of carriers based on scientific misunderstanding continues today ${ }^{66}$

An example of stronger anti-discrimination protection is Alabama, which has prohibited health insurers from denying coverage based on a person's sickle-cell anemia diagnosis. Alabama Code Section 27-5-13 states that insurers are "prohibited from denying coverage to applicants because the applicant has been diagnosed as having sickle-cell anemia." ${ }^{97}$ Because this law prohibits discrimination based on a person's medical diagnosis of sickle-cell anemia, and not their status as a carrier of the sickle trait, this law is not necessarily concerned with genetic discrimination (or genetics at all). At the time, this law would have provided significant protections for those with sickle cell anemia since it was enacted prior to the Affordable Care Act's bar on health insurers considering pre-existing conditions. However, because this law deals with a

\footnotetext{
${ }^{63}$ Sickle Cell Disease (SCD), CTRS. For Disease Control \& Prevention (Oct. 21, 2019), https://www.cdc.gov/ncbddd/sicklecell/traits.html.

${ }^{64}$ See generally Aaron C. Miller et al., supra note 57.

${ }^{65}$ Kenen \& Schmidt, supra note 60, at 1116.

${ }^{66}$ See, e.g., Jennifer K. Wagner, Genetic Discrimination Case Against School District is Appealed to Ninth Circuit, PRIVACY REP. (2016), https://theprivacyreport.com/2016/02/02/genetic-discrimination-case-against-school-districtis-appealed-to-ninth-circuit/ (discussing the case of a boy who was transferred schools because he was a carrier of a genetic variant linked to cystic fibrosis).

${ }^{67}$ ALA. Code $§ 27-5-13$ (2020).
} 
diagnosed medical condition, rather than a trait or carrier status, we did not include it in our coding for a particular trait.

3. Requirements that Use of Genetic Information in Insurance Be Actuarially Justified

A requirement that use of genetic information be actuarially justified is by far the most common anti-discrimination framework method of regulating the use of genetic information in insurance. The business of insurance requires a certain amount of discrimination between individuals because different people present different risks. Thus, in many ways, the business of insurance is the business of lawful discrimination. But most states have passed Unfair Trade Practices Acts (UTPAs) which place limits on the types of discrimination that an insurer may legally engage in. In many cases, UTPAs require bases for discrimination to be actuarially justified—failure to do so would constitute illegal 'unfair discrimination'. Actuarial justification is the requirement that the information used to underwrite or set premiums is statistically related to the risk being underwritten. Thus, an actuarial justification law requires insurers to justify their bases for discriminating between risk groups. For example, in auto insurance, those with more speeding tickets are on average likely to have more accidents and therefore cost more in claims, so considering a history of speeding citations in underwriting would be actuarially justified. It is important to note that in many instances, the general UTPA requirements against unfair discrimination would apply to all information, including use of genetic information ${ }^{68}$, but this paper focuses on those laws that are specific to genetic testing.

\footnotetext{
${ }^{68}$ See Draft Uniform Law, supra note 17 at 14; see also Mark A. Rothstein, Genetic Exceptionalism and Legislative Pragmatism, 35 J.L. MED. \& ETHICs 59, 63 (2007) (“Every state, however, already has unfair trade practice laws that are applicable to life insurance and which require that, to be lawful, underwriting based on any test
} 
In the context of genetic testing, laws generally state that genetic information can be used as long as the information is linked to increased risk. Seven states-Kansas, Maine, Massachusetts, New Jersey, New Mexico, Vermont, and Wisconsin-require actuarial justification for use of genetic information in life insurance. ${ }^{69}$ Eight states-Idaho, Kansas, Maine, Massachusetts, New Jersey, New Mexico, Vermont, and Wisconsin-require it for use in disability insurance. ${ }^{70}$ Six states-Kansas, Maine, Maryland, Massachusetts, New Mexico and Vermont-require it for use in long-term care insurance. ${ }^{71}$ As noted above, Maryland has a law that requires actuarial

must be actuarially justified. The new laws thus appear to address the issue of genetics and life insurance but actually afford no new protections.").

${ }^{69}$ KAN. STAT. ANN. § 40-2259(d) (West 2020) ("An insurer writing life insurance, disability income insurance or long-term care insurance coverage that obtains [genetic] information ... shall not ... provide for rates or any other aspect of coverage that is not reasonably related to the risk involved.”); ME. REv. STAT. ANN. tit. 24A, § 2159-C(3) (2020) ("Discrimination in life, disability, and long-term care insurance. An insurer may not make or permit any unfair discrimination against an individual in the application of genetic information or the results of a genetic test in the issuance, withholding, extension or renewal of an insurance policy . ..."); MASS. GEN. LAWS ANN. ch. 175, § $120 \mathrm{E}$ (West 2020) ("No insurer . . . authorized to issue policies on the lives of persons in the commonwealth shall practice unfair discrimination against persons because of the results of a genetic test or the provision of genetic information .... ."); N.J. STAT. ANN. § 17B:30-12(f) (West 2020) (“No person shall make or permit any unfair discrimination against an individual in the application of the results of a genetic test or genetic information in the issuance, withholding, extension or renewal of a policy of life insurance, including credit life insurance, an annuity, disability income insurance contract or credit accident insurance coverage."); N.M. STAT. ANN. § 24-21-3(D) (West 2020) ("Actions of an insurer ... in the ordinary course of conducting and administering the business of life, disability income or long-term care insurance are exempt from the provisions of this [informed consent] section if the use of genetic analysis or genetic information for underwriting purposes is based on sound actuarial principles or related to actual or reasonably anticipated experience."); VT. STAT. ANN. tit. 129, § 4724 (West 2020) (Unfair acts of business include " $[\mathrm{m}]$ aking or permitting any unfair discrimination against any individual by conditioning insurance rates, the provision or renewal of insurance coverage, or other conditions of insurance based on medical information, including the results of genetic testing, where there is not a relationship between the medical information and the cost of the insurance risk that the insurer would assume by insuring the proposed insured."); WIS. STAT. ANN. § 631.89 (West 2020) (“An insurer writing life insurance coverage or income continuation insurance coverage that obtains [genetic] information ... may not ... provide for rates or any other aspect of coverage that is not reasonably related to the risk involved.").

${ }^{70}$ IdAho Code $\S 41-1313$ (2020); Kan. STAT. ANN. § 40-2259(d) (West 2020); ME. Rev. Stat. tit. 24A, § 2159-C (2020); MASS. GEN. LAWS ch. 175, § 108I (2020) ("No insurer . . . authorized to issue policies against disability from injury or disease or policies providing for long term care in the commonwealth shall practice unfair discrimination against persons because of the results of a genetic test or the provisions of genetic information ...."); Mont. Code AnN. § 33-18-206 (West 2020); N.J. Rev. Stat. § 17B:30-12 (2013); N.M. StAT. ANN. § 24-21-3(D) (2015); V.T. Stat. AnN. tit. 129, § 4724 (West 2020); Wis. StAT. AnN. § 631.89 (West 2009).

${ }^{71}$ Kan. Stat. AnN. § 40-2259(d) (West 2020); ME. Rev. Stat. tit. 24A, § 2159-C (2020); Md. Code AnN., Ins. § 18-120(c) (West 2020) (" $[I] f$ the use is based on sound actuarial principles, the results of a genetic test or genetic information may be used to: 1) deny or limit the amount, extent, or kind of long-term care insurance coverage made available to an individual; or 2) charge a different rate for the same long-term care insurance."); MASS. GEN. LAWS ch. 175, § 108I (2020), N.M. STAT. ANN. § 24-21-3(D) (2015); V.T. STAT. ANN. tit. 129, § 4724 (West 2020). 
justification for life and disability insurance, but only for carrier status for specific diseases, so we categorized this as other.

Kansas' actuarial justification law explicitly applies to life, long-term care, and disability insurance, but it is less-than-clearly articulated. Kansas Statute Section 40-2259(b) prohibits an insurance company from requiring or requesting "directly or indirectly any individual or a member of the individual's family to obtain a genetic test." Subsection (c), however, excludes life, longterm care, and disability insurers from this prohibition as long as they comply with subsection (d)(2), which states that insurers "shall not ... provide for rates or any other aspect of coverage that is not reasonably related to the risk involved." Wisconsin's statute uses essentially the same language. Here, the requirement that rates be "reasonably related" to the risk is tantamount to having an actuarial justification.

Actuarial justification turns on an assessment of available data. Unfortunately, the nature of the data surrounding morbidity and mortality linked to a specific genetic test result often does not allow for straightforward assessments. The sample sizes are often small, the relevance of other medical and environmental factors is often unclear (though increasingly recognized), and data on the impact of mitigating strategies - for example receiving regular colonoscopies if diagnosed with Lynch syndrome - is also often lagging or missing. It is the insurer who is making the assessment of this data. Compounding the patchwork nature of state laws in this area, states differ as to how much deference to give to insurers in the ratemaking process. ${ }^{72}$ They also differ as to the extent to which insurers are required to explain why an individual receives the decision they do. Without a check on the insurance industry, these laws do little to actually protect individuals. Additionally,

\footnotetext{
${ }^{72}$ NAT'L AsSOC. InS. COMM'R, State InSURANCE Regulation 3 (2011), https://www.naic.org/documents/topics_white_paper_hist_ins_reg.pdf (noting the variability in rate review, but that life insurers are often not highly regulated in this area).
} 
there is a question about what genetic-specific actuarial laws add to existing industry regulation and norms. First, many states already require that insurer use of all data, such as medical data or behavioral traits, be actuarially justified. Second, it is in an insurer's interest to properly classify risk. If one insurer is calculating risk more accurately than another, they should be able to pull lower-risk customers away from the competitor. So why might laws that explicitly require actuarial justification for use of genetic information exist? Genetic information is often viewed as exceptional, in large part because of the closely intertwined history of eugenics and genetics. Given past misunderstanding of genetic risk across society, the laws could be seen as necessary to require careful analysis of genetic risk. Second, sometimes these laws are a result of compromise between proponents of regulation and the insurance industry. For example, in some cases these laws started as bills that offered stronger, genuine anti-discrimination protections that would block the use of genetic information regardless of the known impacts of that genetic information, but were amended through insurance company lobbying efforts to these much weaker forms. ${ }^{73}$

Some states have attempted to give some teeth to the requirement of actuarial justification. For example, both New Jersey and Massachusetts laws give the insurance commissioner the power to issue a cease and desist if it is determined that an insurer is using information without actuarial justification. ${ }^{74}$ During the 2019 Florida session, an amendment was proposed that would have required actuarial justification, but also require the insurers to "document the rationale for such action and provide the documentation to the office upon request." ${ }^{, 75}$ While these proposals and laws provide some check on insurers to have documented actuarial justification, the system

\footnotetext{
${ }^{73}$ Md. Dep' t Health \& Mental Hygiene, 2008 Session Position Paper, H.B. 0029, Gen. Assem., Reg. Sess., at 20 (Md. 2008); see also Born, supra note 13, at 14 (noting that in Florida, for example, an amendment that would have converted the protections to requirements of actuarial justification, was proposed, but not ultimately adopted).

${ }^{74}$ MAss. GEN. LAwS ch. 175, § 108I (2020); N.J. REV. STAT. § 17B:30-12 (2013).

${ }^{75}$ See Born, supra note 13, at 14.
} 
generally gives great deference to insurers. This coupled with lack of transparency makes it difficult for consumers to identify lack of actuarial justification and secure protection under these

laws.

\section{Other Approaches}

Although informed consent, prohibitions on use of genetic tests broadly or on use of specific tests, and requirements of actuarial justification are the most common categories of restrictions related to life, long-term care, and disability insurer use of genetic information, there are a handful of other state policies worth noting. ${ }^{76}$

\section{$\underline{\text { Genetic information of relatives }}$}

Two states, Oregon and Vermont, restrict insurers from using the genetic information of a person's relatives, although one statute in Vermont allows use of this information if it is housed in

\footnotetext{
${ }^{76}$ ARIz. REv. STAT. ANN. § 20-448 (2020) (prohibiting insurers from refusing to consider an application on the basis of a genetic condition); FLA. STAT. ANN. § 760.40(3) (West 2020) ("The notice must state that, upon the request of the person tested, the information will be made available to his or her physician. The notice must also state whether the information was used in any decision to grant or deny any insurance, employment, mortgage, loan, credit, or educational opportunity. If the information was used in any decision that resulted in a denial, the analysis must be repeated to verify the accuracy of the first analysis, and if the first analysis is found to be inaccurate, the denial must be reviewed.") (Note, however, that the new Florida law limits the impact of this notice requirement in the context of insurance.); 410 ILL. COMP. STAT. 513/20(e) (2020) (“A company providing direct-to-consumer commercial genetic testing is prohibited from sharing any genetic test information or other personally identifiable information about a consumer with any health or life insurance company without written consent from the consumer."); KY. REV. STAT. ANN. § 304.12-085(3) (West 2020) (“[A]n insurer offering a disability income plan may not request or require an applicant, participant, or beneficiary to disclose to the plan or insurer any genetic test about the participant, beneficiary, or applicant.”); ME. REV. STAT, tit. 24A, § 2159-C(4) (2020) (“Use of information obtained through direct-to-consumer genetic testing. In connection with the issuance, withholding, extension or renewal of an insurance policy for life, credit life, disability, long-term care, accidental injury, specified disease, hospital indemnity or credit accident insurance or an annuity, an insurer may not request, require, purchase or use information obtained from an entity providing direct-to-consumer genetic testing without the informed written consent of the individual who has been tested."); N.H. Rev. STAT. AnN. § 141-H:5(2) (2020) (“A person in the business of providing life, disability income, or long-term care insurance who obtains information with respect to any genetic testing of an individual or a member of the individual's family shall not use that information in writing a type of insurance coverage other than life, disability income, or long-term care insurance."); N.M. STAT. ANN. § 2421-3 (West 2020) (requiring insurers to notify that genetics may be used); N.Y. INS. LAW § 2615(e) (McKinney 2020) (requiring insurers to notify an individual of an adverse underwriting decision and send results to the individual's physician upon request) (as noted above, the Maryland statute combining actuarial justification and traits is also coded as other).
} 
the individual's medical record. ${ }^{77}$ As discussed above, a recent bill in the state legislature would have altered this language and create a stronger bar on use of all genetic information. New York has a provision related to the genetic information of a relative that prohibits insurers from incorporating the information of a relative into the records of an individual without consent. ${ }^{78}$

\section{Requiring a test}

Massachusetts (in disability and long-term care), Maryland (in long-term care), and Vermont disallow insurers from requiring an individual to undertake genetic testing. ${ }^{79}$ This framework would allow insurers to consider existing genetic information absent other restrictions, but would prevent them from requiring the individual to undertake testing. Other states take a different approach. California (in disability and life) and Minnesota (in life), for example, allow insurers to require genetic testing, but only if the insurer pays for the cost of the testing. ${ }^{80}$ These two states plus New York and New Jersey (in disability and life) also have provisions that encourage or require genetic test results to be returned through a physician or other healthcare provider. $^{81}$

\section{$\underline{\text { Beneficial genetic information }}$}

Oregon stands alone in its approach to prohibit individuals from using genetic information to "induce" insurance. ${ }^{82}$ The statutory language is not completely clear as "induce" is not further

\footnotetext{
77 OR. ReV. StAT. ANN. $§ 746.135$ (4) (West 2020) (“A person may not use genetic information about a blood relative to reject, deny, limit, cancel, refuse to renew, increase the rates of, affect the terms and conditions of or otherwise affect any policy of insurance.”); VT. STAT. ANN. tit. 18, § 9334(a) (West 2020).

${ }^{78}$ N.Y. INS. LAW $\S 2615$ (h) (McKinney 2005) ("No authorized insurer who lawfully possesses information derived from a genetic test on a biological sample from an individual shall incorporate such information into the records of a non-consenting individual who may be genetically related to the tested individual; nor shall any inferences be drawn, used, or communicated regarding the possible genetic status of the non-consenting individual.").

${ }^{79}$ Md. Code AnN., Ins. $§ 18-120$ (West 2020); MASS. GEN. Laws ch. 175, § 120E (West 2020); Id. § 108I; V.T. STAT. ANN. tit. 18, § 9334(a) (1999).

${ }^{80}$ CAL. INS. CODE $§ 10148$ (West 2020) (requiring life and disability income insurers to pay for the cost of a genetic test); Minn. STAT. ANN. $\S 72$ A.139(7) (West 2020) (requiring life insurers to pay for a genetic test).

${ }^{81}$ C.A. InS. CODE $\S 10148$ (West 2019) (section applicable to life and disability income insurers); MinN. STAT. $\S$ 72A.139 (2020); N.J. STAT. ANN. § 17B:30-12 (West 2020); N.Y. INS. LAW § 2615(e) (McKinney 2005).

${ }^{82}$ Or. Rev. Stat. AnN. $§ 746.135$ (West 2020).
} 
defined in this part of the code. The intent of the original legislation was presumably to prevent insurers "skimming off" those applicants with better genetic risks. The practice of identifying those who are at lower risk and offering them lower rates is a common business practice in all lines of insurance. However, the use of beneficial genetic information in insurance underwriting complicates the status of bans on use. The classic example of the use of beneficial genetic information is a woman with a family history of breast cancer who tests negative for the familial BRCA mutation. Without the genetic information, she could be charged a higher rate based on her family history. ${ }^{83}$ If state law prohibits the use of genetic information, as in the case of Florida, this woman may be forced to accept the higher rate based on her family history.

Whether or not insurers should be able to consider beneficial genetic information is an open policy question. On the one hand, it seems unfair that a person who did not inherit a family mutation should be charged a higher rate based on family history. On the other, allowing use of beneficial genetic information could threaten protections that bar insurers from considering nonbeneficial genetic information. This is because insurers may begin to assume that anyone who does not provide beneficial genetic information carries the familial risk and charge them more-even without specifically looking at genetic test results.

\section{The Problems with Patchwork}

Despite the varied methods of legislation discussed above, the use of genetic information in life, long-term care and disability insurance is still comparatively unregulated. Half of U.S. states have no legislation that directly addresses how life, long-term care, and disability insurers may use genetic information. Of the 25 that do regulate the use in some way, few ban insurers

\footnotetext{
${ }^{83}$ K. Barlow-Stewart et al., How Are Genetic Test Results Being Used by Australian Life Insurers?, 26 EuR. J. HuM. GENETICs 1248, 1253 (2018) (showing that in Australia this is how insurers are commonly using genetic information in underwriting).
} 
from using genetic information. Instead, they are most likely to rely on strategies of informed consent or requiring actuarial justification for use of genetic test results. These policy strategies, however, do little to address privacy and discrimination concerns of the public because they fail to account for the power differentials between applicants and insurers. The informed consent laws may provide information to individuals, but those who do not wish to consent may face denial of insurance or increased premiums. Actuarial justification frameworks, the primary antidiscrimination approach used, provide individuals with little recourse given the lack of transparency in insurance underwriting and the general deference given to insurers by the regulatory system to make underwriting decisions. Put simply, the existing patchwork of varied state protections is inadequate to provide the protections against genetic discrimination across insurances.

The lack of strong anti-discrimination protections across the states does little to address sustained fear of genetic discrimination in the country. This fear of discrimination leads individuals to decline genetic testing in both clinical and research settings - a trend that has negative consequences for the public health of society. ${ }^{84}$ Some may argue that use of genetic information in these lines of insurance is not widespread enough to warrant comprehensive regulation. ${ }^{85}$ However, there have been a number of bills introduced in legislatures across the country in recent years. These bills, other than the Florida effort, have so far been successfully quashed or watered

\footnotetext{
${ }^{84}$ Mark A. Rothstein, supra note 15, at 794; see also Laura M. Amendola et al., Why Patients Decline Genomic Sequencing Studies: Experiences from the CSER Consortium, J. GENETIC COUNSELING 1220, 1225 (2018) (stating that thirteen percent of individuals declined participation in a genetic research study because of privacy and discrimination concerns).

${ }^{85}$ See Jessica L. Roberts, Preempting Discrimination: Lessons from the Genetic Information Nondiscrimination Act, 63 VAND. L. REV. 437, 462 (2010) (outlining a major critique of GINA - that it was passed before there was a need for the law).
} 
down by the insurance industry, but it is likely that there will continue to be state-level regulatory efforts until stronger regulation is achieved. ${ }^{86}$

Many past commentators have raised the concerns that the current patchwork of state laws fails to adequately address fear of discrimination and does not sufficiently fill in the gap of protections in GINA. ${ }^{87}$ However, the variability of state laws itself leads to problems. The US system of federalism allows for issues to be addressed at the local level, as states can best address the unique circumstances of their constituents. ${ }^{88}$ This is one of the primary reasons why regulation of insurance has remained predominantly at the state level, not the federal level. ${ }^{89}$ Varied state level regulation of insurer use of genetic information, however, raises specific problems for individuals, families and their healthcare providers and insurers alike.

A. Understanding legal protections

There have been multiple efforts by researchers to map the landscape of laws that regulate the use of genetic information across society and in insurance specifically. These efforts make clear that it is difficult to comprehensively and consistently survey the legal landscape of genetic anti-discrimination laws. As noted throughout this paper, different efforts to catalog genetic antidiscrimination laws have interpreted the statutes in different ways. This is because state legislation is complex and often requires nuanced interpretation and analysis based on specific facts.

1. Difficulties with communicating laws at the point of informed consent

\footnotetext{
${ }^{86}$ Anya E.R. Prince, Political Economy, Stakeholder Voices, and Saliency: Lessons from International Policies Regulating Insurer Use of Genetic Information, 5 J.L. \& BIOSCIENCES 461, 469, 490-92 (2019) (arguing that the political saliency of genetic discrimination will lead to these types of bills continuously introduced until protections are secured).

${ }^{87}$ See, e.g., Amy L. McGuire \& Mary Anderlik Majumder, Two Cheers for GINA, 1 GENOME MED. 6 (2009).

${ }^{88}$ A possible example of this ability of state legislatures to focus on issues particularly pertinent to their constituents is those states that chose to legislate on sickle cell trait, all of which have large African American populations (North Carolina, Tennessee, Florida, Maryland, Alabama).

${ }^{89}$ McCarran-Ferguson Insurance Regulation Act of 1945, ch. 20, 59 Stat. 33 (1945) (codified as amended at 15 U.S.C. $\S \S 1011-15$ (2012)); NAT’L ASSOC. INS. COMM’R, supra note 72, at 2 ("State insurance regulatory systems are accessible and accountable to the public and sensitive to local social and economic conditions.").
} 
Individuals deciding whether to undergo a genetic test are expected to make an informed decision based on their values. This is the case in all branches of medicine, but a particular emphasis is placed on autonomy within genetics, and the genetic counselling profession is dedicated to ensure this is upheld. Likewise in clinical research, an individual is expected to make an informed choice about whether or not to participate based on an understanding of the complete range of potential risks and benefits, including social risks like insurance discrimination. But individuals often do not have access to relevant state laws at the point of consent. And even if they do have access, it is unclear how to interpret the protections that the laws offer.

One problem is that it is often not lawyers transmitting this complex material to the public. Instead, individuals are most likely to learn of genetic anti-discrimination protections from an informed consent process for clinical or research genetic testing ${ }^{90}$ and subsequent discussions with healthcare providers or researchers. If the legal landscape is difficult for lawyers to parse, imagine how difficult it is for healthcare providers and researchers to determine the scope of protections. What's more, non-lawyers are barred from practicing law, so nuanced analysis of the applicability of a state law to a particular individual's situation by healthcare providers and researchers is also tricky. Providers can give general descriptions of legal protections, such as the general description of GINA that is recommended for genetic testing informed consent. ${ }^{91}$ However, the more complex and variable the information, the harder it is to boil down into succinct, clear, and accurate generalities. For this reason, most informed consent language simply describes GINA and the gap in protections for life, long-term care, and disability insurances, without going into specifics about

\footnotetext{
90 See, e.g., Genetic Information Nondiscrimination Act Guidance (2009), U.S. DEP'T HEALTH \& HUM. SERVS. (Mar. 21, 2016), https:/www.hhs.gov/ohrp/regulations-and-policy/guidance/guidance-on-genetic-informationnondiscrimination-act/index.html; see also Alicia A. Parkman et al., Public Awareness of Genetic Nondiscrimination Laws in Four States and Perceived Importance of Life Insurance Protections, 24 GENETIC COUNSELING 512, 515 (2015) (showing that knowledge of GINA is generally very low across the public).

${ }^{91}$ U.S. DEP'T HEALTH \& HuM. SERVS., supra note 90.
} 
any state law protections. ${ }^{92}$ The result is that a segment of individuals undergoing genetic testing fails to learn about the protections they may have at the state level. Even if state laws currently provide relatively weak protections, there is still value in individuals understanding the true scope of their legal protections in this area. Thus, the patchwork of state laws has the potential to create confusion for individuals due to the difficulty in determining what laws actually apply and in learning complete and accurate information from healthcare and research systems. ${ }^{93}$

2. Similar words, different meanings

The difficulties surrounding informing the public of their legal rights are compounded by the variability of definitions of key terms across jurisdictions, and in particular the definition of "genetic information". There are three common variations in this definition that will alter the scope of protections for individuals in the state.

First, laws vary as to whether genetic information is narrowly defined to results of a genetic test, or whether it includes broader information. GINA defined genetic information to include not just the results of a genetic test, but also some obvious proxies for genetic predispositions, such as family medical history, participation in genetic research, and use of genetic services. ${ }^{94}$ By contrast, state law in this area generally is limited to test results, and sometimes is even more narrowly prescribed. For example, while GINA prohibits health insurers from considering family medical history, the new Florida legislation specifically excludes 'questions regarding family history' from the definition of genetic information. ${ }^{95}$

\footnotetext{
${ }^{92}$ See, e.g., Resources, CLINICAL SEQUENCING EXPLORATORY RES., https://cser1.cser-consortium.org/resources (visited Aug. 12, 2020) (providing sample consent forms used by participating researchers in the Clinical Sequencing Exploratory Research (CSER) consortium); see also Wolf et al., supra note 12, at 83 (noting why it may be ethically and legally problematic to ignore state law variation in research projects).

${ }^{93}$ Wolf et al., supra note 12, at 79-80 ("The quantity of state laws is striking, standing alone, as it points to the complexity of identifying what protections are afforded to research participants and communicating those protections effectively to participants.").

9429 U.S.C.A. § 1191(b)(6) (West 2020).

${ }^{95}$ FLA. STAT. ANN. § 627.4301(1)(a) (West 2020).
} 
Second, it is common in state definitions of genetic test or genetic information to include language that genetic information is that which is associated with increased risk of disease. ${ }^{96} \mathrm{New}$ Mexico, as an illustration, defines genetic testing as "a test of an individual's DNA, ribonucleic acid, chromosomes or proteins, including carrier status, that are linked with physical or mental disorders, impairments or genetic characteristics or that indicate that an individual may be predisposed to an illness, disease, impairment or other disorder." ${ }^{\text {"97 }}$ In contrast, a number of states use definitions that do not include a statistical link. For example, New Jersey defines genetic information to be "information about genes, gene products or inherited characteristics that may derive from an individual or family member." 98 The upshot is that there may be types of genetic information that fall through the cracks if there is a requirement that the information be linked to predispositions for disease. ${ }^{99}$ Notably, there are some genetic test results-called variants of uncertain significance - where testing laboratories are unclear as to whether or not the genetic changes are linked to disease. It is also possible that genetic tests of the future for non-disease traits, such as risk aversion, may be of interest to insurers. ${ }^{100}$ Consumers would be unprotected in states that require association with disease.

Third, definitions differ as to whether they cover only predictive genetic information or whether they also include diagnostic genetic information. Some states, such as Maryland, narrow

\footnotetext{
${ }^{96}$ See, e.g., ARIz. REv. STAT. ANN. § 20-448 (2020) (““Genetic test' means an analysis of an individual's DNA, gene products or chromosomes that indicates a propensity for or susceptibility to illness, disease, impairment or other disorders, whether physical or mental ....”); Del. CoDE ANN. tit. 16, § 1201 (West 2020) (“'Genetic information' means information about inherited genes or chromosomes, and of alterations thereof ... that is scientifically or medically believed to predispose an individual to disease, disorder or syndrome or believed to be associated with a statistically significant increased risk of development of a disease, disorder or syndrome."). ${ }^{97}$ N.M. STAT. ANN. § 24-21-2(F) (West 2015).

${ }^{98}$ N.J. REV. STAT. § 17B:30-12 (2013).

${ }^{99}$ Kayte Spector-Bagdady et al., supra note 24.

${ }^{100}$ Richard Karlsson Linnér et al., Genome-Wide Association Analyses of Risk Tolerance and Risky Behaviors in Over One Million Individuals Identify Hundreds of Loci and Shared Genetic Influences, 51 NATURE GENETICS 245, 245 (2019).
} 
their definitions of genetic information only to predictive genetic information. ${ }^{101}$ Montana and Arizona provide another example of the fine line between predictive and diagnostic genetic information. Both states bar the rejection of an application or a change in rates based on "a genetic condition, developmental delay or developmental disability."102 In these states 'genetic condition' is defined as a specific chromosomal or single-gene genetic condition, thus cabining protections to a narrow set of diagnosed conditions.

Other state definitions include both diagnostic or predictive genetic tests. ${ }^{103}$ This distinction between predictive and diagnostic information is complicated by the existence of diagnoses based on genetic variation that increases the risk for certain conditions, for example the diagnosis of hereditary breast and ovarian cancer syndrome for BRCA carriers, even in the absence of a diagnosis of cancer.

These variable definitions have the possibility to increase misunderstanding of legal protections if different types of 'genetic information' are protected at different levels of government and across states. The myriad of legal definitions make it even more difficult to parse protections and clearly explain available protections to individuals. The rapid evolution of types of genetic tests in use compounds this challenge, for example the introduction of epigenetic tests,

\footnotetext{
${ }^{101}$ MD. CODE ANN., INS. § 18-120(2)(i) (West 2020) ("Genetic information means information derived from a genetic test: 1. About chromosomes, genes, gene products, or inherited characteristics that may derive from an individual or a family member; 2 . Not obtained for diagnostic and therapeutic purposes; and 3. Obtained at a time when the individual to whom the information relates is asymptomatic for the disease, disorder, illness, or impairment to which the information relates.").

${ }^{102}$ Mont. Code ANN. § 33-18-206(4) (West 2020) ("The rejection of an application or the determining of rates, terms, or conditions of a life or disability insurance contract on the basis of genetic condition ... constitutes unfair discrimination unless the applicant's medical condition and history and either claims experience or actuarial projections establish that substantial differences in claims are likely to result from the genetic condition ...."); see also ARIz. Rev. STAT. ANN. § 20-448(E) (2020).

${ }^{103}$ VT. STAT. ANN. tit. 18, $\S 9331$ (West 2020) ("Genetic testing means a test, examination, or analysis that is diagnostic or predictive of a particular heritable disease or disorder and is of: (i) a human chromosome or gene; (ii) human DNA or RNA; or (iii) a human genetically encoded protein.").
} 
and makes it more difficult to ensure that legislation is up to date when there are multiple laws, rather than just one central policy, to amend.

B. Variable laws in practice

1. Which state law applies?

While individuals often learn of genetic anti-discrimination protections through informed consent, the state where consent occurs is not always the state where the individual is getting their insurance. US-based individuals frequently move or work across state boundaries. Take, for example, an individual who lives in Vermont and is interested in a renewal of his term life insurance policy. During the process of renewal, his insurance company requests that he undertake a genetic test. ${ }^{104}$ In Vermont, insurers are allowed to consider genetic information during insurance renewal if there is actuarial justification ${ }^{105}$; however, they are not allowed to require an individual to take a genetic test. ${ }^{106}$ So, is this insurer's action illegal? Not necessarily. If, for example, the individual originally got his insurance in another state or receives insurance through an employer located in a different state, that state's law could apply.

These issues may not frequently arise in the context of genetic testing, since questions about the use of genetic testing are most likely to come up during the initial underwriting of a policy and individuals are most likely to be applying for insurance in a state where they currently reside. However, to the extent that any confusion does arise, this adds complexity to an already

\footnotetext{
${ }^{104}$ Note, there is not necessarily evidence that this type of request is happening on a regular or widespread basis. This example is used to illustrate questions that could arise if insurers began to adopt such practices. 105 Md. Code AnN., Ins. § 27-208(b)(3)(ii) (West 2016); Vt. StAT. AnN. tit. 129, § 4724(7)(B)(ii) (West 2020).

${ }^{106}$ Md. Code AnN., Ins. § 27-208(c)(ii) (West 2016); Vt. StAT. AnN. tit. 18, § 9334(a) (West 2020).
} 
complex patchwork and threatens to make individuals more skeptical of protections that are in place. When minimizing fear of genetic discrimination is one primary goal of anti-discrimination legislation, increased skepticism threatens the success of any legislation.

2. Joint genetic information; disjointed protection

Genetic information is shared across families: a mother and son will share about $50 \%$ of their DNA; first cousins will share about $12.5 \%$. These family members, however, will not necessarily live in the same state and therefore may have divergent protections related to the same genetic information. The significant drawback of this situation is all the starker when thinking about particular familial variants, especially those related to diseases that can be prevented.

Take for example, the case of Lynch Syndrome - a genetic predisposition to colon and endometrial cancer. Identifying individuals with Lynch Syndrome, before they develop symptoms, could lead to public health gains since frequent colonoscopies can help to prevent cancer in individuals with Lynch Syndrome. For example, the Michigan Department of Health and Human Services has tools to help healthcare providers identify individuals at risk for hereditary cancer, including Lynch Syndrome. ${ }^{107}$ Once one individual in the family is identified as having a genetic variant linked to Lynch Syndrome, other family members can get tested for this particular familial variant - a process known as cascade testing. Cascade testing can be a cheaper and more effective way of identifying at-risk individuals since the test for the specific familial variant is less costly than broader genetic testing and this is a way to identify those at-risk before they develop symptoms.

${ }^{107}$ Guide to Hereditary Cancer Indications for Referral, MI GENETICS RES. CTR., https://migrc.org/cancer-risk/ (last visited Aug. 12, 2020). 
However, a patchwork system of legal protections could thwart efforts of cascade testing. For example, imagine that an individual in Colorado is concerned about her family history of colon and endometrial cancer. Her genetic counselor recommends that her mother, who has previously had a polyp removed during a colonoscopy, be tested first. Her mother, however, lives in neighboring Kansas and is worried about access to long-term care insurance. While a long-term care insurer in the daughter's state would not be able to consider genetic information, the Kansas insurer could consider the mother's genetic information if there was actuarial justification.

Similarly, the vast majority of states allow insurers to consider the genetic test results of family members. Therefore, an individual may opt to delay recommended testing out of concern that their actions could affect the ability of family members to get insurance, even if that individual lives in a state with greater protections, such as Florida.

3. Navigating variability as an insurer

Individuals and their families would benefit from more consistent regulation, but so too could insurers. For the most part insurance is regulated by the states, but the challenge for national companies to abide by 50 different sets of laws is compounded by legislators reacting to rapidly evolving technologies.

Determining the impact of a new law that restricts the ability of insurers to price according to risk, as is the case with the new law in Florida, is complex. The impact of these strong antidiscrimination protections is particularly hard to predict because individuals are not constrained to buying insurance in their state of residence. This leaves open the possibility of insurance tourism, whereby individuals with adverse genetic test results could buy insurance in states that offered the strongest protections. Before the new legislation passed in Florida, the vice president of a free market think tank raised this possibility: one effect would be that insurance agents nationwide 
would advise clients, "Take a weeklong vacation in the state of Florida and buy a \$1 million life insurance policy while you're there." ${ }^{108}$ It is unclear whether insurance tourism will occur, and if it does, whether it will occur at a scale significant enough to affect insurers. If so, it could contribute to adverse selection, the process by which individuals with higher risk self select into insurance risk pools, thus leaving insurers unable to meet their commitments. In the worst case scenario, this could drive insurers to abandon business in states with strong legislative protections. This is a particular concern for the long-term care insurance market, which is already very weak. ${ }^{109}$ C. Achieving uniformity in practice

For the reasons outlined above, the current status of a patchwork of protections is inadequate. There are several ways that uniform policy and regulation could be established in this area. First, legislation aimed at filling the gaps left open by GINA could be adopted at the federal level. While this would create uniform regulation across the country, it may be difficult for advocates to secure Congressional efforts at this time. Second, there are several existing organizations that draft model laws aimed at establishing a uniform approach to regulation in insurance and other fields. The model laws are proposals, but help to increase uniformity as states pass the legislation that is coordinated at a national level. Three existing groups could be natural candidates to develop model laws in this area. The Uniform Law Commission has already considered a draft model law for use of genetic information in insurance. Although this draft was never approved, the group did adopt a model law for genetic discrimination in employment. Two

\footnotetext{
${ }^{108}$ Drew Wilson, Insurance Summit: Genetic Testing Could Lead to Lower Premiums, Fla. Politics (Nov. 5, 2019), https://floridapolitics.com/archives/310427-insurance-summit-genetic-testing-could-lead-to-lower-premiums (quoting the VP of the James Madison Institute, Sal Nuzzo).

109 Eric C. Nordman, The State of Long-Term Care Insurance: The Market, Challenges and Future INNOVATIONS, NAT'L ASSOC. INS. COMM'R, 33-34 (2016),

https://naic.org/documents/cipr_current_study_160519_ltc_insurance.pdf. (explaining both insurer supply and consumer demand for long-term care insurance are low, despite the widespread acknowledgement of the desirability, and growing relevance, of this line of insurance).
} 
national insurance groups also utilize model laws. The National Association of Insurance Commissioners (NAIC) and the National Conference of Insurance Legislators (NCOIL) both develop model laws for the insurance industry and could develop one on this topic. ${ }^{110}$ Third, the US could adopt an approach taken by many international countries where the insurance industry, possibly in coordination with a government entity, establishes a moratorium on the use of genetic information in underwriting. Finally, another approach taken in other countries is for industry groups to proliferate uniform practice standards regarding use of genetic information. ${ }^{111}$

Achieving uniformity across the states is essential, but it is also important to consider uniformity in how the law applies to various entities. We have focused on the three lines of nonhealth insurance that most commonly use medical underwriting, and hence are most likely to incorporate genetic information. But the insurance industry is constantly innovating, and health data is increasingly being integrated into diverse settings. Future legislative efforts should hence not limit themselves to just these three lines of insurance as other insurances, such as auto or homeowners, could be interested in the underwriting on the basis of genetic predispositions. Beyond insurance, other actors, such as lenders or educational facilities could also be regulated in use of genetic information.

\section{Conclusion}

Our first conclusion is that the variability in protections for those individuals who have undergone genetic testing and who seek to buy or renew life, disability, or long-term care insurance

\footnotetext{
${ }^{110}$ NAIC Model Laws, Regulations, Guidelines and Other Resources, NAT'L Assoc. INS. COMM'R, https://www.naic.org/prod_serv_model_laws.htm (last reviewed Aug. 12, 2020) (outlining dozens of newly developed model laws, including fourteen in life insurance, four in long-term care insurance, and one in disability income insurance. Members commit to attempts at passage in their home states and uptake is often good.).

${ }^{111}$ See generally Robert H. Jerry, II, The Antitrust Implications of Collaborative Standard Setting by Insurers Regarding the Use of Genetic Information in Life Insurance Underwriting, 9 CoNN. INS. L.J. 397 (2002) (presenting antitrust cases that are applicable to insurers if they agree on uniform business practices, such as underwriting factors).
} 
has negative consequences for consumers, for medical professionals, and also for insurers. More consistency is needed, and there are several potential paths forward to achieving this. Previous work looking across several lines of insurance and various attributes of individuals which are sometimes protected in insurance law (for example sex and race) concluded that there is no clear underlying consistent philosophy to the protections that have been enacted. ${ }^{112}$ The lack of consistency in protecting individuals against genetic discrimination is hence not surprising. But we have argued that variability in this domain raises unique concerns. Namely, because the status quo makes it hard for individuals to give truly informed consent, because individuals move across state lines despite having consented to genetic testing in a different jurisdiction, and because many individuals will learn that they are recommended to undergo genetic testing because of results received by a family member in a different state.

Our second conclusion is that most existing state legislation does not address the key problem. As we have shown, almost all existing legislation prevents insurers from inaccurately using genetic risk information, something they are already incentivized to avoid. Moreover, these laws leave the power of interpretation of genetic results to insurers. Rights given to individuals, preventing the inaccurate use of genetic information and ensuring informed consent in some circumstances, do not take the power differential between the individual and an insurance company into account. Very few states have legislation that protects individuals even if they are found to have genetic variation linked to increased risk. The holes in the protections offered by GINA thus continue to gape. These gaps in protection matter because they are coupled to health outcomes. Only bans on the use of genetic information offer protections strong enough to reassure individuals

\footnotetext{
${ }^{112}$ See generally Ronen Avraham et al., Towards a Universal Framework for Insurance Anti-Discrimination Laws, 21 CONN. INS. L.J. 1 (2014) (noting there is an implicit reliance on three factors: the predictive nature of the trait, the potential for adverse selection, and concerns of illicit discrimination of the trait generally).
} 
contemplating undergoing genetic testing that the results will not be used against them. Fear of this possibility puts many off genetic testing. It is hence these stronger protections that are needed to help ensure the promise of genomic medicine. 